\title{
Histopathological Features of Gastrointestinal Stromal Tumors and the Contribution of DOG1 Expression to the Diagnosis
}

\author{
Beril Güler ${ }^{1}$, Filiz Özyılmaz², Burcu Tokuç³, Nuray Can², Ebru Taştekin² \\ ${ }^{1}$ Department of Pathology, Bezmialem Vakıf University Faculty of Medicine, İstanbul, Turkey \\ ${ }^{2}$ Department of Pathology, Trakya University Faculty of Medicine, Edirne, Turkey \\ ${ }^{3}$ Department of Public Health, Trakya University Faculty of Medicine, Edirne, Turkey
}

Background: Gastrointestinal stromal tumors (GIST) have KIT or platelet-derived growth factor receptor $\alpha$ (PDGFR $\alpha$ ) mutations affecting receptor tyrosine kinase activity and do not benefit from classic treatment regimens.

Aims: The aim of this study was to review the algorithm that may be followed for the diagnosis and differential diagnosis in GISTs by investigating the histomorphological parameters and expression characteristics of classical immunohistochemical antibodies used in routine tests in addition to DOG1 expression.

Study Design: Diagnostic accuracy study.

Methods: We reevaluated the histological and immunohistochemical parameters of 37 GISTs. The standard immunohistochemical diagnosis and differential diagnosis panel antibodies (CD117, PDGFR $\alpha$, CD34, vimentin, desmin, SMA, S-100, and Ki67) were studied on the tumor sections. We also used the popular marker DOG1 antibody with accepted sensitivity for GISTs in recent years and the PDGFR $\alpha$ immune marker for which the benefit in routine practice is discussed.

Results: Classification according to progressive disease risk groups of the 37 cases revealed that $54 \%$ were in the high risk, $19 \%$ in the moderate risk, $16 \%$ in the low risk, $8 \%$ in the very low risk and $8 \%$ in the no risk group.

Cytological atypia, necrosis, mucosal invasion and the Ki67 index were found to be related to the progressive disease risk groups of the tumors $(\mathrm{p}<0.05)$.

Positive immunoreaction was observed with CD117 and PDGFR $\alpha$ in all GISTs in the study (100\%). Positivity with the DOG1 antibody was found in $33(89 \%)$ cases. CD34 was positive in $62 \%$ (23) of the cases.

Conclusion: The CD117 antibody still plays a key role in GIST diagnosis. However, the use of DOG1 and PDGFR $\alpha$ antibodies combined with $\mathrm{CD} 117$ as sensitive markers can be beneficial.

Keywords: CD117, DOG1, gastrointestinal stromal tumors, histopathology, immunohistochemistry, PDGFR $\alpha$
Gastrointestinal stromal tumors (GISTs) are relatively rare but still the most common mesenchymal tumors of the gastrointestinal system (GIS). The importance of true diagnosis of GISTs has been emphasized due to the fact that they are a model in targeted treatment regimens and there are developments in treatment protocols currently in progress (1).

Immunohistochemical (IHC) findings of GISTs published in the literature have been developed for the last 25 years. The

This study was presented at the $23^{\text {rd }}$ National Pathology Congress, 6-10 November 2013, İzmir, Turkey.

Address for Correspondence: Dr. Beril Güler, Department of Pathology, Bezmialem Vakıf University Faculty of Medicine, İstanbul, Turkey Phone: +90 5062889997 e-mail: berilgus@yahoo.com

Received: 18.10.2014 Accepted: 09.05.2015 - DOI: 10.5152/balkanmedj.2015.15912

Available at www.balkanmedicaljournal.org

Cite this article as:

Güler B, Özyılmaz F, Tokuç B, Can N, Taştekin E. Histopathological features of gastrointestinal stromal tumors and the contribution of DOG1 expression to the diagnosis.

Balkan Med J 2015;32:388-96. 
first studies have focused on the expression of myoid and neural antigens, but the results were inconsistent. A hematopoietic stem cell determinant CD34 was subsequently tried and found to be expressed in most GISTs in all locations. It was concluded in recent years that immunoexpression of CD117 (c-kit) as an IHC marker of intestinal Cajal cells, which are the origin cells of GISTs, is a gold standard for final diagnosis in tumors, revealing locations and morphological findings that are consistent with GIST (1). However, CD117 expression has not been demonstrated in certain cases, especially PDGFR $\alpha$ mutant or wild types. The GIST1 (DOG1) antibody has therefore been added to the diagnostic panel as an alternative marker to accompany CD117 in the routine diagnostic algorithm for GISTs (2-11).

The DOG1 gene is located on the CCND1-EMS1 loci of human chromosome 11q13 (12-13). This gene contains 26 exons and encodes a 960-amino-acid protein of approximately $114 \mathrm{~Kb}$. Basic DNA sequence analyses have identified 8 transmembrane domains in this protein. Its function is not known, but the high number of transmembrane zones suggests that it acts as an ion channel $(12,14)$. The gene product, known as TMEM16A (transmembrane protein 16A), was found to be a calcium-dependent chloride channel protein, consistent with the initial hypotheses, and was renamed anoctamin1 (ANO1) (1,15-17).

There are many articles which have discussed the correct diagnosis of gastrointestinal stromal tumors and their prognosis. After the evaluation of many parameters, the National Institutes of Health (NIH) published a consensus in 2002 based on morphological findings for use as a reference for the diagnosis and evaluation of the prognosis of GISTs (18). Following the publication of this consensus, a couple of larger clinicopathological studies have been published by the Armed Forces Institute of Pathology (AFIP), which provide important information for understanding the biology of these tumors $(1,19,20)$. This risk stratification table is the current schema that is generally used in studies and clinical routine evaluations.

The aim of this study was to review the algorithm that may be followed for the diagnosis and differential diagnosis in GISTs by investigating the histomorphological parameters and expression characteristics of classical immunohistochemical antibodies used in routine tests in addition to DOG1 expression.

\section{MATERIALS AND METHODS}

\section{Patient selection and histopathological evaluation}

We included 37 tumor resection materials diagnosed as GIST from Trakya University Faculty of Medicine. Department Archive cases between 1995 and 2010 in the study. The age, gender, tumor localization, type of surgery, and tumor di- ameter of the cases were recorded from the pathology reports. Hematoxylin-eosin (HE)-stained slides of the paraffin blocks representing tumors were classified according to the criteria of AFIP/2006 (Miettinen et al.) (1) and NIH/2002 (Fletcher et al.) (18) and then reevaluated in terms of histopathological parameters (number of mitoses in $50 \mathrm{HPF}$, cellularity, cell type, cytological atypia, bleeding, necrosis, mucosal invasion, multifocality, recurrence and metastasis).

The local ethics committee approved the study design (No: TUTFEK 2009/1185).

\section{Immunohistochemistry}

CD117 (clone C-19, polyclonal rabbit, 1/200, Santa Cruz, Texas, USA), DOG1 (clone SP31, monoclonal rabbit,1/50, Thermo Scientific, Fremont, USA), CD34 (clone QBEnd/10, monoclonal mouse, $1 / 200$, Thermo Scientific, Fremont, USA), PDGFR $\alpha$ (clone C-20, polyclonal rabbit, 1/250, Santa Cruz, Texas, USA), vimentin (clone V9, monoclonal mouse, $1 / 200$, Biocare Medical, Concord, USA), SMA (clone 1A4, monoclonal mouse, $1 / 100$, Biocare Medical, Concord, USA), S-100 (clone 4C4.9, polyclonal mouse, ready to use, ScyTek, Utah, USA), desmin (clone D33, monoclonal mouse, 1/25, Biocare Medical, Concord, USA), Ki67 (clone SP6, monoclonal rabbit, 1/100, Biocare Medical, Concord, USA) antibodies were studied with the Streptavidin-Biotin indirect immunoperoxidase method on the $4 \mu \mathrm{m}$ thick tumor sections obtained from formalin-fixed paraffin blocks. The control tissue for CD117, DOG1 and PDGFR $\alpha$ consisted of the tumor block in which the GIST diagnosis was verified by 2 pathologists (BG, FÖ) using morphological and immunohistochemical features. The ethylene diamine-tetra-acetic acid buffer (EDTA buffer, Code: 15-M820, Lot.50930, Bio-optica, Milano, Italy) solution diluted 1:10 with distilled water at $\mathrm{pH} 8.0$ in a microwave oven was added to all antibodies for the antigen retrieval process. The AEC chromogen (Ref: ACD 030, Lot.18618, ScyTek, Utah, USA) was used as a counter-stain.

\section{Immunohistochemical scoring}

Cytoplasmic immunoreaction over $10 \%$ of the evaluated slide was accepted as positive for vimentin, desmin, CD34, PDGFR $\alpha$, SMA, and S-100. All cases were recorded as positive or negative. Various scoring methods have been used to evaluate the expression of CD117 and DOG1 in tissues in the literature $(2,4,6,21-25)$. We used the following criteria for the evaluation of CD117 and DOG1 expression according to the extent of staining: $0-10 \%$ staining (negative), $10-50 \%$ staining (focal), and $>50 \%$ staining (diffuse). The intensity of staining was classified as: $(+)$ mild, $(++)$ moderate, and $(+++)$ strong (21-23). Regardless of staining intensity, immunoexpression for the other markers was scored according to the extent of 
TABLE 1. Clinicopathological features and comparison with risk groups of GIST cases

\begin{tabular}{|c|c|c|c|}
\hline Clinicopathological features & $\mathrm{n}$ & $(\%)$ & $\mathrm{p}$ value ${ }^{\dagger}$ \\
\hline \multicolumn{4}{|l|}{ Risk of malignancy } \\
\hline High risk group & 20 & (54) & \\
\hline Other risk groups & 17 & $(46)$ & \\
\hline Sex & & & $0.905^{* * *}$ \\
\hline Female & 22 & $(59.5)$ & \\
\hline Male & 15 & $(40.5)$ & \\
\hline Age & & & $0.442 *$ \\
\hline Median & 57.2 & $(23-74)$ & \\
\hline Female/median & 58.6 & $(23-71)$ & \\
\hline Male/median & 55.1 & $(41-74)$ & \\
\hline \multicolumn{4}{|l|}{ Tumor site $^{z}$} \\
\hline Stomach & 11 & $(29.7)$ & \\
\hline Small intestine & 19 & $(51.4)$ & \\
\hline Colon & 4 & $(10.8)$ & \\
\hline Retroperitoneum & 3 & $(8.1)$ & \\
\hline \multicolumn{4}{|l|}{ Tumor size ${ }^{*}$} \\
\hline$\leq 2 \mathrm{~cm}$ & 1 & $(2.7)$ & \\
\hline$>2$ to $\leq 5 \mathrm{~cm}$ & 10 & $(27.1)$ & \\
\hline$>5$ to $\leq 10 \mathrm{~cm}$ & 13 & $(35.1)$ & \\
\hline$>10 \mathrm{~cm}$ & 13 & $(35.1)$ & \\
\hline \multicolumn{4}{|l|}{ Tumor cell type $\mathrm{e}^{*}$} \\
\hline Spindle & 20 & $(54.1)$ & \\
\hline Epithelioid & 1 & $(2.7)$ & \\
\hline Mixed & 16 & $(43.2)$ & \\
\hline Cytologic atypia & & & $0.031 * * *$ \\
\hline Low & 19 & $(51.4)$ & \\
\hline High & 18 & $(48.6)$ & \\
\hline \multicolumn{4}{|l|}{ Cellularity $^{*}$} \\
\hline Low & 4 & $(10.8)$ & \\
\hline High & 33 & $(89.2)$ & \\
\hline Hemorrhage & & & $0.596^{* *}$ \\
\hline Present & 30 & $(81.1)$ & \\
\hline Necrosis & & & $0.033^{* * *}$ \\
\hline Present & 26 & $(70.1)$ & \\
\hline Ulceration & & & $0.058^{* *}$ \\
\hline Present & 10 & $(27.0)$ & \\
\hline Mucosal invasion & & & $0.013 * * *$ \\
\hline Present & 12 & $(32.4)$ & \\
\hline Mitoses & & & $0.000^{*}$ \\
\hline$\leq 5 / 50 \mathrm{HPF}$ & 18 & $(48.6)$ & \\
\hline$>5 / 50 \mathrm{HPF}$ & 19 & $(51.4)$ & \\
\hline Ki 67 proliferation index & & & $0.003 * * *$ \\
\hline Cut off $<10$ & 23 & $(62.2)$ & \\
\hline
\end{tabular}

TABLE 1. Continued

\begin{tabular}{|c|c|c|}
\hline Cut off $>10$ & 14 & $(37.8)$ \\
\hline \multicolumn{3}{|c|}{ Adjacent tissue invasion ${ }^{*}$} \\
\hline Present & 9 & $(24.3)$ \\
\hline \multicolumn{3}{|l|}{ Multifocality ${ }^{*}$} \\
\hline Present & 5 & $(13.5)$ \\
\hline \multicolumn{3}{|l|}{ Recurrence $^{*}$} \\
\hline Present & 3 & $(8.1)$ \\
\hline \multicolumn{3}{|l|}{ Metastasis $^{z}$} \\
\hline Lymph node & 3 & $(8.1)$ \\
\hline Liver & 4 & $(10.8)$ \\
\hline
\end{tabular}

†: Clinicopathological features have been obtained by comparing high risk and other risk groups; ${ }^{*}$ : Statistical methods were not used;

*: Mann-Whitney U test; **: Fisher's Exact test; ***: Pearson Chi Square test GIST: gastrointestinal stromal tumor

staining; staining in $0-10 \%$ of the sample was accepted as negative, staining in $10-50 \%$ of the sample was accepted as focal positive, and staining in $>50 \%$ of the sample was accepted as diffuse positive. The Ki67 antibody was studied on tissues with the highest mitotic index and the percentage of nuclear positivity in 1000 cells was determined.

\section{Statistical analysis}

Statistical analyses were performed in SPSS for Windows Version 16.0 (SPSS Inc., Chicago, IL, USA). After performing normality tests, Clinicopathological features were compared by risk groups, using Pearson Chi Square tests, Fisher's Exact test, Mann-Whitney U test and Kruskal-Wallis test. The correlation analysis of the antibody (CD117, DOG1, Ki67) expressions with risk groups was done by using Spearman Correlation Analysis. A p $<0.05$ was accepted as significant in all tests.

\section{RESULTS}

\section{Clinical and histopathological examination}

The 37 GIST cases making up the study group were reevaluated according to the risk categorization based on "the risk of progressive disease" $(1,18)$. The clinicopathological characteristics are presented in Table 1. The age distribution was 23-74 years. More than half of the cases were localized in the small intestine $(51.4 \%)$. The tumor size varied between 0.6 and $24 \mathrm{~cm}$ (mean diameter $9.3 \mathrm{~cm}$ ) (Table 2, Figure 1).

There were 20 (54.1\%) high risk, 7 (18.9\%) moderate risk, $6(16.2 \%)$ low risk, and $3(8.1 \%)$ very low risk cases, with 1 $(2.7 \%)$ no risk case. We then classified the cases according to the malignancy risk groups into two groups as those with high 
TABLE 2. Relationship between tumor location and age, sex, tumor size, and progressive disease risk of GISTs

\begin{tabular}{|c|c|c|c|c|c|c|c|}
\hline Tumor Location & $\begin{array}{c}\text { Age* } \\
\text { Mean } \pm \text { Std deviation } \\
\text { (minimum/maximum) }\end{array}$ & $\begin{array}{c}\text { Diameter cm* } \\
\text { Mean } \pm \text { Std deviation } \\
(\text { minimum/maximum })\end{array}$ & $\begin{array}{c}\text { No } \\
\text { Risk \% } \\
\end{array}$ & $\begin{array}{c}\text { Very Low } \\
\text { Risk \% }\end{array}$ & $\begin{array}{c}\text { Low } \\
\text { Risk \% }\end{array}$ & $\begin{array}{c}\text { Moderate } \\
\text { Risk \% }\end{array}$ & $\begin{array}{c}\text { High } \\
\text { Risk \% }\end{array}$ \\
\hline Stomach $(\mathrm{n}=11)$ & $59.5 \pm 9.5(43-69)$ & $8.7 \pm 4.6(3-16)$ & 0 & 3 & 3 & 2 & 3 \\
\hline Small Intestine ( $\mathrm{n}=19)$ & $54.4 \pm 12.2(23-70)$ & $9.1 \pm 4.5(3.5-18)$ & 0 & 0 & 3 & 5 & 11 \\
\hline Large Bowel $(n=4)$ & $58.0 \pm 8.3(52-70)$ & $8.9 \pm 5.6(0.6-13)$ & 1 & 0 & 0 & 0 & 3 \\
\hline Retroperitoneum ( $\mathrm{n}=3$ ) & $65.3 \pm 12.5(51-74)$ & $13.7 \pm 10.5(3-24)$ & 0 & 0 & 0 & 0 & 3 \\
\hline Total $(\mathrm{n}=37)$ & $57.2 \pm 11.2(23-74)$ & $9.3 \pm 5.1(0.6-24)$ & $1(2.7)$ & $3(8.1)$ & $6(16.2)$ & $7(18.9)$ & $20(54.1)$ \\
\hline
\end{tabular}

*: Kruskal Wallis Variance analysis; $\mathrm{p}=0.888$

TABLE 3. Relationship between cytologic atypia and mitoses, and risk group of GISTs

\begin{tabular}{lcccccccc}
\hline & \multicolumn{3}{c}{ Mitoses* } & & \multicolumn{3}{c}{ Risk Classification **广 } \\
\cline { 2 - 3 } Cytologic Atypia & $\leq 5 / 50 \mathrm{HPF}$ & $>5 / 50 \mathrm{HPF}$ & & No Risk & Very Low Risk & Low Risk & Moderate Risk & High Risk \\
\hline Low & 13 & 6 & & $1(5 \%)$ & $3(16 \%)$ & $4(21 \%)$ & $4(21 \%)$ & $7(37 \%)$ \\
High & 5 & 13 & & $0(0 \%)$ & $0(0 \%)$ & $2(11 \%)$ & $3(17 \%)$ & $13(72 \%)$ \\
\hline
\end{tabular}

*: Pearson $\chi^{2}=6.112, \mathrm{p}=0.013$; *: Pearson $\chi^{2}=4.659, \mathrm{p}=0.031$

†: For statistical analyses, risk groups were classified as high risk and other risk groups.

GIST: gastrointestinal stromal tumor

TABLE 4. Immunohistochemical results

\begin{tabular}{lcccccccc}
\hline $\begin{array}{c}\text { Vimentin } \\
\mathrm{n}(\%)\end{array}$ & $\begin{array}{c}\mathrm{CD} 117 \\
\mathrm{n}(\%)\end{array}$ & $\begin{array}{c}\text { PDGFR } \\
\mathrm{n}(\%)\end{array}$ & $\begin{array}{c}\text { DOG1 } \\
\mathrm{n}(\%)\end{array}$ & $\begin{array}{c}\text { CD34 } \\
\mathrm{n}(\%)\end{array}$ & $\begin{array}{c}\text { SMA } \\
\mathrm{n}(\%)\end{array}$ & $\begin{array}{c}\text { S100 } \\
\mathrm{n}(\%)\end{array}$ & $\begin{array}{c}\text { Desmin } \\
\mathrm{n}(\%)\end{array}$ \\
\hline GIST $\mathrm{n}=37$ & $37(100)$ & $37(100)$ & $37(100)$ & $33(89)$ & $23(62)$ & $2(5)$ & $1(3)$ & $0(0)$ \\
\hline GIST: gastrointestinal stromal tumor
\end{tabular}

risk ( 20 cases) and others (included no risk, very low risk, low risk, and moderate risk groups; 17 cases) as the low number of cases in certain groups otherwise prevented the use of a statistical method and statistically compared the clinicopathological features with these groups (Table 1).

There was a statistically significant association between the tumor risk groups (according to high risk and all other risk groups) and mean tumor size ( $\mathrm{p}=0.007)$, number of mitoses $(\mathrm{p}=0.000)$ cytological atypia $(\mathrm{p}=0.031)$, necrosis $(\mathrm{p}=0.033)$ and mucosal invasion $(\mathrm{p}=0.013)$, while no significant relationship was found with gender, age, bleeding and mucosal ulcer (Table 1) (Figure 2). A proportional relationship was present between presence of cytological atypia and number of mitoses $(\mathrm{p}=0.013)$ (Table 3).

No statistical comparison was made between the groups of progressive risk of disease and the tumor region, tumor size, cellularity, tumor cell type, adjacent tissue invasion, multifocality, recurrence or metastasis rate due to the inadequate number of cases.

\section{Immunohistochemical findings}

Positive immunoreaction with vimentin, CD117 and PDGFR $\alpha$ was observed in all cases. There was positive reaction for CD34 in $23(62 \%)$ and SMA in $2(5 \%)$ cases and for the S-100 antibody in $1(3 \%)$ case. Desmin was negative in all cases (Table 4, Figure 3).

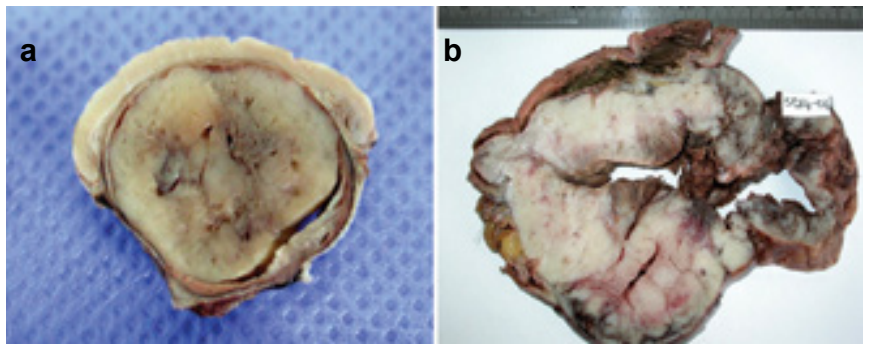

FIG. 1. a, b. The macroscopic appearances of GIST; $4 \mathrm{~cm}$ diameter solid tumor in the gastric wall, moderate risk (a), $18 \mathrm{~cm}$ diameter hemorrhagic and necrotic tumor in the ileum wall, high risk (b) (GIST: gastrointestinal stromal tumor)

Comparing the number of mitoses with the staining pattern of CD117 in tumoral tissue showed that the mean number of mitoses in the cases with focal and/or weak CD117 positivity (31.40 \pm 22.07 in 5 cases) to be significantly higher than in the strong and diffuse cases (10.43 \pm 11.85 in 32 cases) (MannWhitney $\mathrm{U}$ test, $\mathrm{p}=0.038$ ). Generally diffuse and strong cytoplasmic positive reaction with DOG1 was found in $33(89 \%)$ cases (Figure 4). There was mild decrease in intensity and extent of DOG1 positivity with increasing risk group but this was not statistically significant (Fisher's exact test; $\mathrm{p}=0.367$ ), (Table 5).

When tumor risk groups and the Ki67 proliferation index were compared, the Ki67 ratio was over $10 \%$ in $60 \%$ of cases with high risks. A Ki67 proliferation index higher than $10 \%$ in the high risk group was found to be statistically significant (Pearson $\chi^{2} ; \mathrm{p}=0.003$ ). 

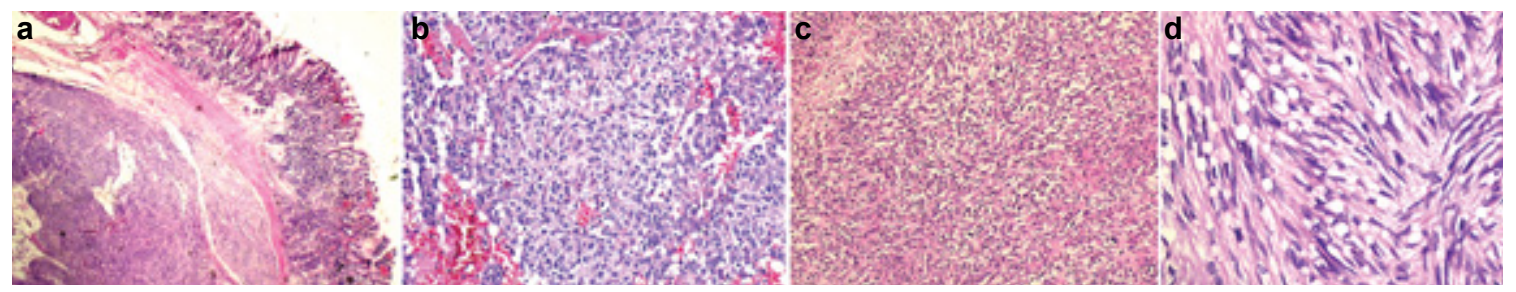

FIG. 2. a-d. GIST case, expansive nodular tumor in the gastric submucosa, H\&E (x12.5) (a), epithelioid type tumor cells, H\&E (x100) (b), spindle cell GIST, hypercellularity, H\&E (x100) (c), spindle cell type, characteristic subnuclear vacuoles H\&E (x100) (d) (GIST: gastrointestinal stromal tumor)

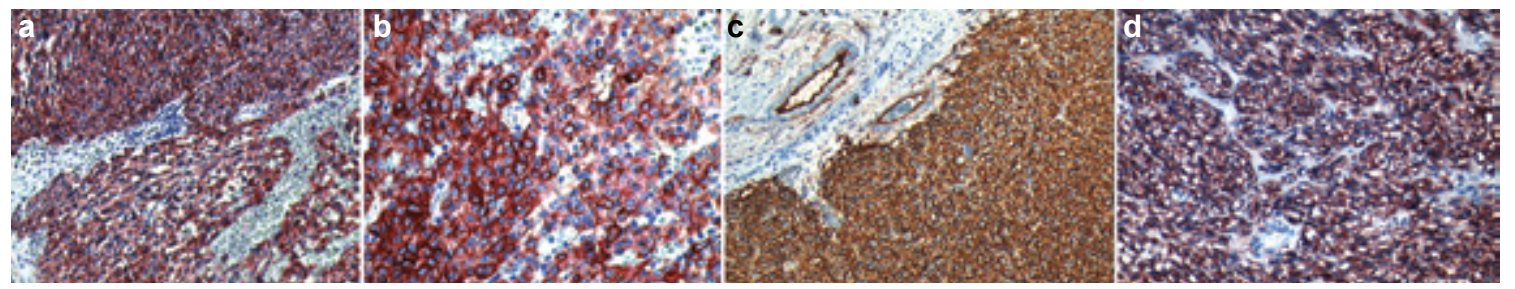

FIG. 3. a-d. In GIST; Strong and diffuse expression of CD117, membranous and cytoplasmic staining (x100) (a) and (x200) (b). CD34 positivity (x100) (c), PDGFR $\alpha$ expression (x100) (d) (GIST: gastrointestinal stromal tumor; PDGFRa: platelet-derived growth factor receptor $\alpha$ )

TABLE 5. Correlation between DOG1 immunoexpression and risk groups of GISTs

\begin{tabular}{|c|c|c|c|c|c|c|c|c|c|}
\hline \multirow[b]{2}{*}{ Risk Categorization $^{\dagger}$} & \multicolumn{2}{|c|}{ DOG1* } & \multicolumn{4}{|c|}{ DOG1 Intensity** } & \multicolumn{3}{|c|}{ DOG1 extent of staining $* * *$} \\
\hline & $(-) \mathrm{n}(\%)$ & $(+) \mathrm{n}(\%)$ & - & + & ++ & +++ & $<10 \%$ & $10-50 \%$ & $>50 \%$ \\
\hline NR & $0(0 \%)$ & $1(100 \%)$ & 0 & 0 & 0 & 1 & 0 & 0 & 1 \\
\hline VLR & $0(0 \%)$ & $3(100 \%)$ & 0 & 0 & 3 & 0 & 0 & 0 & 3 \\
\hline LR & $1(17 \%)$ & $5(83 \%)$ & 1 & 0 & 1 & 4 & 1 & 0 & 5 \\
\hline MR & $0(0 \%)$ & $7(100 \%)$ & 0 & 0 & 1 & 6 & 0 & 0 & 7 \\
\hline HR & $3(15 \%)$ & $17(85 \%)$ & 3 & 2 & 3 & 12 & 3 & 1 & 16 \\
\hline TOTAL & $4(11 \%)$ & $33(89 \%)$ & 4 & 2 & 8 & 23 & 4 & 1 & 32 \\
\hline
\end{tabular}

NR: no risk; VLR: very low risk; LR: low risk; MR: moderate risk; HR: high risk; *: Fischer certain $\chi^{2} \mathrm{p}=0.367$; **: Spearman correlation; $\mathrm{p}=0.897$; **: Spearman correlation; $\mathrm{p}=0.292$

: For statistical analyses, risk groups were classified as high risk and other risk groups.

\section{DISCUSSION}

Gastrointestinal stromal tumors have been previously described as tumors of the gastrointestinal system with mesenchymal character in which the origin could not be identified and the tumor did not respond to classic treatment; however, we are now able to identify and determine the origin of these tumors. The development of new-targeted treatment regimens could create models for molecular medicine by taking the biology of these tumors into account $(11,21,22)$. GISTs currently make up about $80 \%$ of mesenchymal tumors developing in the GIS (23). They constitute less than $1 \%$ of all gastrointestinal tumors (24).

Although GISTs can be detected in all organs along the gastrointestinal (GI) tract with different biological behaviors, they are most commonly seen in the stomach (50-70\%) and small intestine $(20-40 \%)(11,26-29)$. GISTs are less common in the rectum, esophagus, omentum and mesentery, with an

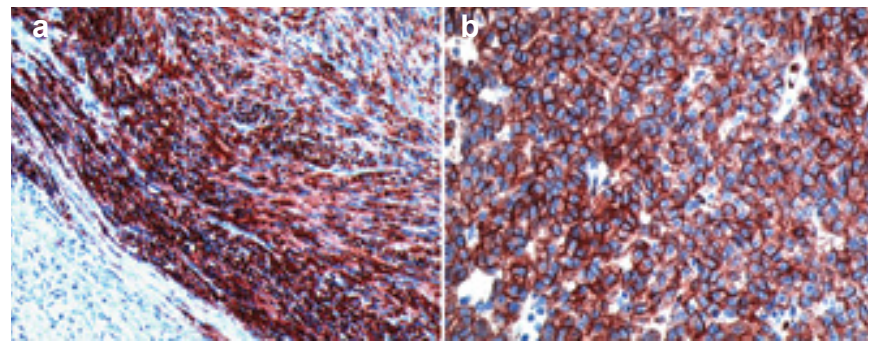

FIG. 4. a, b. In GIST; Strong and diffuse expression of DOG1, membranous and cytoplasmic (x100) (a), (x200) (b) (GIST: gastrointestinal stromal tumor)

incidence of 5-10\% and in regions outside the GI tract with an incidence of $<5 \%(30,31)$. The most common location in our cases was the small intestine (51.4\%) followed by the stomach (29.7\%). Many studies have reported anatomical localization as an independent prognostic factor in GISTs. GISTs located in the small intestine have a worse prognosis than those in the stomach with similar diameter and mitotic activity $(19,20)$. 
Clinically malignant behavior is seen in $40-50 \%$ of intestinal GISTs and about $20-25 \%$ of gastric GISTs (1). We found high risk features, an indicator of aggressive behavior, in $58 \%$ of cases with a small intestine location and $27 \%$ of cases located in the stomach in our study.

Tumor size and mitotic rate have been accepted as the most reliable parameters by many authors for determining prognosis $(1,18,32)$. A tumor diameter less than $2 \mathrm{~cm}$ reduces the risk of progressive disease in all locations. A tumor larger than 5 $\mathrm{cm}$ in small intestine tumors and larger than $10 \mathrm{~cm}$ in gastric tumors was reported to be a poor prognostic factor when large series were investigated and classified according to localization in a more recent article of the same group of authors $(19,20)$. Recurrent tumors and tumors with liver metastasis in our cases were larger; tumor diameter sizes were consistent with the literature findings.

The number of mitoses indicates active growth in the tumor. Five or fewer mitoses per $50 \mathrm{HPF}$ is associated with low risk groups. However, it is especially emphasized that tumors with a mitotic index less than 10/50 HPF, but with other malignancy criteria can show malignant behavior too (27). The average number of mitoses per 50 HPF was 15.25 (5-12-1430 mitoses) in 4 of our cases with liver metastasis. Although there was a proportional relationship between malignant behavior and high mitotic index, recurrence occurred in one of the GISTs with 4 mitoses per 50 HPF localized in the small bowel, which was exceptional. This may be explained by the greater tumor size despite the low mitotic index. Invasion to surrounding tissues was present and the diameter was $10 \mathrm{~cm}$ in our small intestinal case with recurrence, although there were 4 mitoses per $50 \mathrm{HPF}$.

According to NIH (18) and AFIP (1) criteria (based on tumor location, size and mitoses), twenty (54\%) of our 37 GIST cases were classified in the high risk group where malignant behavior is expected. A study presented at the 21st European Pathology Congress reported the classification of 1008 GIST cases gathered from 29 centers in Turkey as high risk in 54\%, moderate in $19 \%$, low risk in $21 \%$ and very low risk in $6 \%$ (33). Another study with patients from 3 Turkish centers reported the distribution as high risk in $47 \%$, moderate risk in $23 \%$, low risk in $16 \%$ and very low risk in $3 \%$ (34). The distribution of our cases according to risk group was consistent with the multi-center studies reflecting the general situation in our country.

Many histological criteria have been tested to predict the prognosis in GISTs, but most of them have not been adequately helpful. Lesions with small diameters (even those smaller than $2 \mathrm{~cm}$ ) and very low mitotic rates have been reported to metastasize. Immunohistochemical studies have been conducted with cell proliferation markers with the aim of being more objective and identifying malignant behavior by many authors and was accepted as an important prognostic marker in terms of a higher than $10 \%$ positive result indicating a high proliferation index $(18,35,36)$. The Ki67 proliferation index was $>10 \%$ in $37.8 \%$ of the GIST cases in our study. Evaluation according to risk group revealed a high proliferation index in $60 \%$ of the cases belonging to the high risk group, while this rate was $11.8 \%$ in other risk groups; the difference was significant $(\mathrm{p}<0.05)$.

Immunohistochemical studies are required in addition to routine HE examinations for the correct diagnosis of these special tumors that show similar morphological appearance and location to other mesenchymal tumors but have a totally different prognosis and treatment (37). GISTs originate from the intestinal cells of Cajal, characterized usually by expression of the KIT protein, and are defined as c-Kit (CD117) immunopositive tumors. Expression of this marker plays a key role during diagnosis. CD117 immunohistochemical expression has been found with mutation analysis studies in PDGFR $\alpha$-mutant and "wild type" GISTs, whereas CD117 can be negative in tumor tissue in c-Kit-mutant GISTs $(1,19,22,28)$. GISTs have been reported to show diffuse and strong staining with CD117 at a rate of $65-100 \%$ in several publications (Table 6) $(2-8,20$ $22,25,29-31,38,39$ ). Positive reaction was seen for CD117 in all our cases and staining was diffuse, with strong staining found in $86 \%$ of the tumors in the study group.

CD34 was considered to be the most valuable marker for GIST diagnosis before identification of the CD117 antibody. CD34 positivity in GISTs varies between 40 and $82 \%$ in the literature $(1,18-20,25,28,40,41)$. Positive immunreaction with CD34 was observed in $62 \%$ of our cases.

Immunohistochemical c-kit positivity was the gold standard in the verification of a GIST diagnosis and CD34 expression was accepted as a diagnostic supportive "marker" until recently. However, KIT negativity or uncertain CD117 expression in a significant number ( 4-15\%) of GISTs and especially PDGFR $\alpha$ mutant cases can cause difficulties in diagnosis $(2,3,6)$. Difficulties with optimization of KIT for IHC procedures can also cause false-positive and -negative results with the KIT marker (2). In 2004, the hypothetical protein-encoding FLJ10261 gene was found to be expressed specifically in GISTs by West et al. (4) for the first time and was named DOG1 $(1,2,16,17)$.

West et al. (4) stated that DOG1 (polyclonal) expression was found in $97.8 \%$ of GISTs by both immunohistochemistry and in situ hybridization, independent of the mutation status in their study. Similarly, 75-99\% staining with the DOG1 antibody was found in GISTs in various studies that were subsequently conducted (2-8). Instead of the polyclonal form of the DOG1 antibody, the K9, DOG1.1 and DOG1.3 monoclonal subtypes that have been reported to be more specific have 
TABLE 6. Comparison of result of studies investigating DOG1 and CD117 expressions in GISTs

\begin{tabular}{lccccc}
\hline & GIST (n) & DOG1/clone & DOG1 (+) (n \%) & CD117 (+) (n \%) & DOG1 (+)/ CD117 (-) (n \%) \\
\hline West et al. (4) & 149 & $\mathrm{pcl}$ & $136 / 139(98)$ & $134 / 144(93)$ & No data \\
Espinosa et al. (3) & 428 & DOG1.1/mcl & $370 / 425(87)$ & $317 / 428(74)$ & $63 / 111(57)$ \\
Miettinen et al. (2) & 1168 & K9/mcl & $1103 / 1168(94)$ & $1106 / 1168(95)$ & $14 / 38(37)$ \\
Liegl et al. (6) & 81 & DOG1.1/mcl & $61 / 81(75)$ & $53 / 81(65)$ & $10 / 28(36)$ \\
Lopes et al. (7) & 668 & DOG1.1/mcl & $538 / 668(81)$ & $643 / 668(96)$ & $5 / 25(20)$ \\
& & K9/mcl & $642 / 668(96)$ & & $19 / 25(76)$ \\
Novelli et al. (8) & 187 & K9/mcl & $184 / 186(99)$ & $176 / 182(97)$ & $7 / 7(100)$ \\
Jung et al. (29) & 81 & No information & $77 / 81(95)$ & $76 / 81(94)$ & $5 / 5(100)$ \\
Sun et al. (30) & 63 & mcl & $53 / 63(84)$ & $57 / 63(91)$ & $6 / 6(100)$ \\
Rios-Moreno et al. (38) & 99 & K9/mcl & $90 / 99(91)$ & $94 / 99(94)$ & $2 / 5(40)$ \\
Kara et al. (31) & 33 & SP31/mcl & $29 / 33(87)$ & $27 / 33(81)$ & $2 / 6(33)$ \\
Guler et al. (Present study) & 37 & SP31/mcl & $33 / 37(89)$ & $37 / 37(100)$ & No case \\
Total & 2994 & & $2778 / 2980(93)$ & $2720 / 2984(91)$ & $128 / 231(55)$ \\
\hline
\end{tabular}

GIST: gastrointestinal stromal tumor; DOG: discovered on GIST; mcl: monoclonal; pcl: polyclonal

been produced and used in various studies $(2-8,29,31,38)$. As summarized in the article of Wong et al. (15), the difference in positivity rates is thought to stem from the sensitivity features of the clone used. We mostly observed a diffuse and strong positive reaction with monoclonal DOG1 (clone SP31) antibody in $89 \%$ (33/37) of the GIST cases in our study. When we classified the cases as high risk and other groups, DOG1 positivity was $85 \%$ in the high risk group and $94 \%$ in the other groups. Although a mild decrease in the intensity and extent of DOG1 expression was found as the risk increased, it was not statistically significant $(\mathrm{p}>0.05)$.

An attempt has been made to define the most specific immunohistochemical panel for the diagnostic algorithm by comparing the expression rates with CD117 in almost all studies with DOG1 in the literature. The rate of DOG1 positivity was $20-100 \%$ in CD117 negative GIST cases in different studies, all of which reported that DOG1 should be added to the immunohistochemical panel in the diagnostic steps independent of the mutation status $(2,6-8,29,31,38,42)$. In the present study, positivity with CD117 was provided by applying the immunohistochemical studies on multiple different paraffin blocks in those cases which could be negative for CD117 (focally and weak reaction). The DOG1 antibody can be useful, especially in high risk tumors exhibiting focal staining with CD117. Also, the staining pattern of CD117 in other tumors should be considered and final diagnosis can be made by including the DOG1 antibody in the immunohistochemical panel in the differential diagnosis.

As summarized in Table 6, collective evaluation of the results of the series where CD117 and DOG1 antibodies were studied together (if we ignore the fact that these studies were performed under different laboratory conditions at different centers and by using different antibody clones) in GISTs $(2-4,6-8,29-31,38)$ revealed that the CD117 positivity rate was $91 \%$ and DOG1 positivity $93 \%$ in about three thousand GIST cases. DOG1 specificity was reported to be a little lower than, equal to or greater than $\mathrm{CD} 117$ specificity in different studies. The rate of DOG1 positivity in CD117 negative cases were reported in a wide range of $20-100 \%$ in the same studies. DOG1 positivity was found in $55 \%$ of the CD117 negative cases in these studies (Table 6) indicating that a little more than half of the CD117 negative cases could be differentiated with the DOG1 antibody.

Lopes et al. (7) found that the K9 clone had higher specificity by studying two different monoclonal clones (DOG1.1 and K9) of the DOG1 antibody in a GIST series of 668 cases. However, the DOG1 positivity rate varies between 37 and $100 \%$ in CD117 negative cases even in studies performed with the DOG1/K9 clone $(2,7,8,38)$. The wide range of DOG1 positivity in CD117 negative cases in such series may be due to the low number of cases, differences among the DOG1 clones used or other unknown factors. We believe that more reliable results can be obtained with studies performed with the same DOG1 clone on a large series at a single center in the future.

PDGFR $\alpha$ gene mutation is a well-defined alternative oncogenic mechanism in GISTs where a classic c-Kit mutation is not found and is present in roughly $6.5 \%$ of GISTs. PDGFR $\alpha$ mutated GISTs are usually immunohistochemically CD117 negative tumors $(42,43)$. Various results have been reported from studies investigating the significance of the PDGFR $\alpha$ immune marker in diagnosis $(6,21,42-44)$. Peterson et al. (43) found immunohistochemical PDGFR $\alpha$ expression in $89.7 \%(35 / 39)$ of GISTs independent of mutation status in their study. Rossi et al. (44) reported that a positive reaction was seen with PDGFR $\alpha$ in all GISTs where c-Kit expres- 
sion was not found. A diffuse and strong positive reaction was usually observed for PDGFR $\alpha$ in all GISTs in our study. However, the benefit of PDGFR $\alpha$ in routine immunohistochemical use was reported to be limited due to the optimization problems in the application of a PDGFR $\alpha$ antibody that can be commercially provided in particular and the inability to prevent intense background staining in more recent publications $(6,21)$.

In conclusion, tumor diameter, mitosis, cytological atypia, necrosis, mucosal invasion and Ki67 index, all of which are accepted as histopathological parameters for progressive disease in the literature, were also found to be associated with high risk in our study. The results showed that immunohistochemical CD117 positivity is still a gold standard as a supportive finding in cases consistent with GIST in terms of tumor location site and histomorphological features. Antibody clone and laboratory conditions for immunohistochemical studies are important for the elimination of false CD117 negativity. However, the DOG1 antibody should be used as an alternative sensitive and specific marker in the immunohistochemical diagnostic panel in tumors with suspicious or negative staining for CD117. The use of PDGFR $\alpha$ as an auxiliary marker together with other antibodies may also be helpful.

Ethics Committee Approval: Ethics committee approval was received for this study from the Local Ethics Committee (No: TUTFEK 2009/1185).

\section{Informed Consent: N/A.}

Peer-review: Externally peer-reviewed.

Author contributions: Concept - F.Ö., B.G.; Design - B.G., F.Ö., B.T., N.C., E.T.; Supervision - F.Ö., B.G.; Resource - F.Ö., B.G., B.T.; Materials - F.Ö., B.G.; Data Collection \&/or Processing - F.Ö., B.G.; Analysis \&/or Interpretation - F.Ö., B.G., B.T.; Literature Search - F.Ö., B.G., N.C., E.T.; Writing - B.G., F.Ö., B.T., N.C., E.T.; Critical Reviews - F.Ö., B.G., N.C., E.T.

Conflict of Interest: No conflict of interest was declared by the authors.

Financial Disclosure: This study was supported by the "Trakya University Scientific Research Projects” unit (TUBAP-2009/124).

Editor-in-chief's note: One of the authors of this article, Burcu Tokuç is the member of the editorial board of Balkan Medical Journal. However, she did not take place at any stage on the editorial decision of the manuscript.

\section{REFERENCES}

1. Miettinen M, Lasota J. Gastrointestinal stromal tumors: review on morphology, molecular pathology, prognosis, and differential diagnosis [review]. Arch Pathol Lab Med 2006;130:1466-78.
2. Miettinen M, Wang ZF, Lasota J. DOG1 antibody in the differential diagnosis of gastrointestinal stromal tumors: a study of 1840 cases. Am J Surg Pathol 2009;33:1401-8. [CrossRef]

3. Espinosa I, Lee CH, Kim MK, Rouse BT, Subramanian S, Montgomery $\mathrm{K}$, et al. A novel monoclonal antibody against DOG1 is a sensitive and specific marker for gastrointestinal stromal tumors. Am J Surg Pathol 2008;32:210-8. [CrossRef]

4. West RB, Corless CL, Chen X, Rubin BP, Subramanian S, Montgomery $\mathrm{K}$, et al. The novel marker, DOG1, is expressed ubiquitously in gastrointestinal stromal tumors arrespective of KIT or PDGFRA mutation status. Am J Pathol 2004;165:107-13. [CrossRef]

5. Ardeleanu C, Arsene D, Hinescu M, Andrei F, Gutu D, Luca L, et al. Pancreatic expression of DOG1 A novel gastrointestinal stromal tumor (GIST) biomarker. Appl Immunohistochem Mol Morphol 2009; 17:413-8. [CrossRef]

6. Liegl B, Hornick JL, Corless CL, Fletcher CD. Monoclonal antibody DOG1.1 shows higher sensitivity than KIT in the diagnosis of gastrointestinal stromal tumors, including unusual subtypes. Am J Surg Pathol 2009;33:437-46. [CrossRef]

7. Lopes LF, West RB, Bacchi LM, van de Rijn M, Bacchi CE. DOG1 for the diagnosis of gastrointestinal stromal tumor (GIST): Comparison between 2 different antibodies. Appl Immunohistochem Mol Morphol 2010;18:333-7. [CrossRef]

8. Novelli R, Rossi S, Rodriguez-Justo M, Taniere P, Seddon B, Toffolatti $\mathrm{L}$, et al. DOG1and CD117 are the antibodies of choice in the diagnosis of gastrointestinal stromal tumours. Histopathology 2010;57:259-70. [CrossRef]

9. Miwa S, Nakajima T, Murai Y, Takano Y, Sugiyama T. Mutation assay of the novel gene DOG1 in gastrointestinal stromal tumors (GISTs). J Gastroenterol 2008;43:531-7. [CrossRef]

10. Lee $\mathrm{CH}$, Liang $\mathrm{CW}$, Espinosa I. The utility of discovered on gastrointestinal stromal tumor 1 (DOG1) antibody in surgical pathology-the GIST of it [review]. Adv Anat Pathol 2010;17:22232. [CrossRef]

11. Demetri GD, von Mehren M, Antonescu CR, DeMatteo RP, Ganjoo KN, Maki RG, et al. NCCN Task Force Report: Update on the management of patients with Gastrointestinal Stromal Tumors. J Natl Compr Canc Netw 2010;8(Suppl 2):S1-41.

12. Katoh M, Katoh M. FLJ10261 gene, located within the CCND1EMS1 locus on human chromosome 11q13, encodes the eight-transmembrane protein homologous to C12orf3, C11orf25 and FLJ34272 gene products. Int J Oncol 2003;22:1375-81. [CrossRef]

13. Galindo BE, Vacquier VD. Phylogeny of the TMEM16 protein family: some members are overexpressed in cancer. Int $J$ Mol Med 2005;16:919-24. [CrossRef]

14. Carles A, Millon R, Cromer A, Ganguli G, Lemaire F, Young $\mathrm{J}$, et al. Head and neck squamous cell carcinoma transcriptome analysis by comprehensive validated differential display. Oncogene 2006;25:1821-31. [CrossRef]

15. Wong NA. Gastrointestinal stromal tumours-an update for Histopathologists. Histopathology 2011;59:807-21. [CrossRef]

16. Caputo A, Caci E, Ferrera L, Pedemonte N, Barsanti C, Sondo E, et al. TMEM16A, a membrane protein associated with calciumdependent chloride channel activity. Science 2008;322:590-4. [CrossRef] 
17. Yang YD, Cho H, Koo JY, Tak MH, Cho Y, Shim WS, et al. TMEM16A confers receptor-activated calcium-dependent chloride conductance. Nature 2008;455:1210-5. [CrossRef]

18. Fletcher CD, Berman JJ, Corless C, Gorstein F, Lasota J, Longley BJ, et al. Diagnosis of gastrointestinal stromal tumors: a consensus approach [review]. Hum Pathol 2002;33:459-65. [CrossRef]

19. Miettinen M, Sobin LH, Lasota J. Gastrointestinal stromal tumors of the stomach: a clinicopathologic, immunohistochemical, and molecular genetic study of 1765 cases with long-term follow-up. Am J Surg Pathol 2005;29:52-68. [CrossRef]

20. Miettinen M, Makhlouf H, Sobin LH, Lasota J. Gastrointestinal stromal tumors of the jejunum and ileum: a clinicopathologic, immunohistochemical, and molecular genetic study of 906 cases before imatinib with long-term follow-up. Am J Surg Pathol 2006;30:477-89. [CrossRef]

21. Liegl-Atzwanger B, Fletcher JA, Fletcher CD. Gastrointestinal stromal tumors [review]. Virchows Arch 2010;456:111-27. [CrossRef]

22. Steigen SE, Eide TJ. Gastrointestinal stromal tumors (GISTs): a review. APMIS 2009;117:73-86. [CrossRef]

23. Nishida T, Hirota S. Biological and clinical review of stromal tumors in the gastrointestinal tract [review]. Histol Histopathol 2000;15:1293-301.

24. Joensuu H. Gastrointestinal stromal tumor (GIST) [review]. Ann Oncol 2006;17:280-6. [CrossRef]

25. Doğanavşargil B, Akalın T, Sezak M, Alkanat BM, Kandiloğlu G, Tunçyürek M. Gastrointestinal stromal tümörlerde histopatolojik değerlendirme "Ege Üniversitesi Tıp Fakültesi Patoloji Anabilim Dalı'nın 1992-2007 yılları arasındaki deneyimi”. Ege Journal of Medicine 2008;47:163-70.

26. Miettinen M, Sarlomo-Rikala M, Lasota J. Gastrointestinal stromal tumors: recent advances in understanding of their biology. Hum Pathol 1999;30:1213-20. [CrossRef]

27. Hou YY, Lu SH, Zhou Y, Xu JF, Ji Y, Hou J, et al. Predictive values of clinical and pathological parameters for malignancy of gastrointestinal stromal tumors. Histol Histopathol 2009;24:737-47.

28. Parfitt JR, Streutker CJ, Riddell RH, Driman DK. Gastrointestinal stromal tumors: A contemporary review [review]. Pathol Res Pract 2006;202:837-47. [CrossRef]

29. Jung SH, Suh KS, Kang DY, Kang DW, Kim YB, Kim ES. Expression of DOG1, PDGFRA, and p16 in gastrointestinal stromal tumors. Gut Liver 2011;5:171-80.

30. Sui XL, Wang H, Sun XW. Expression of DOG1, CD117 and PDGFRA in gastrointestinal stromal tumors and correlations with clinicopathology. Asian Pac J Cancer Prev 2012;13:138993. [CrossRef]

31. Kara T, Serinsoz E, Arpaci RB, Gubur O, Orekici G, Ata A, et al. Contribution of DOG1 expression to the diagnosis of gastrointestinal stromal tumors. Pathol Res Pract 2013;209:413-7. [CrossRef]
32. Miettinen M, El-Rifai W, H L Sobin L, Lasota J. Evaluation of malignancy and prognosis of gastrointestinal stromal tumors: a review. Hum Pathol 2002;33:478-83. [CrossRef]

33. Dogusoy Bulbul G. (GIST Working Group Turkish Society of Pathology, Turkey). Gastrointestinal stromal tumors: Recent results of a nationwide database including 1008 cases with histopathological and immunophenotypical features. 21st European Congress of Pathology. (Oral Presentation), Istanbul. In Virchows Arch 2007;451:161.

34. Selcukbiricik F, Yalçın S, Tural D, Erdamar S, Demir G, Doğusoy G, et al. Gastrointestinal stromal tumors in Turkey: experiences from 3 centers. Onkologie 2013;36:18-24. [CrossRef]

35. Fujimoto Y, Nakanishi Y, Yoshimura K, Shimoda T. Clinicopathologic study of primary malignant gastrointestinal stromal tumor of the stomach, with special reference to prognostic factors: analysis of results in 140 surgically resected patients. Gastric Cancer 2003;6:39-48. [CrossRef]

36. Wong NA, Young R, Malcomson RD, Nayar AG, Jamieson LA, Save VE, et al. Prognostic indicators for gastrointestinal stromal tumours: a clinicopathological and immunohistochemical study of 108 resected cases of the stomach. Histopathology 2003;43:118-26. [CrossRef]

37. Blay JY, von Mehren M, Blackstein ME. Perspective on updated treatment guidelines for patients with gastrointestinal stromal tumors [review]. Cancer 2010;26:1-11. [CrossRef]

38. Rios-Moreno MJ, Jaramillo S, Gallardo SP, Vallejo A, Mora M, Garcia-Escudero A, et al. Gastrointestinal stromal tumors (GISTs): CD117, DOG-1, and PKC $\theta$ expression. Is there any advantage in using several markers? Pathol Res Pract 2012;208:74-81. [CrossRef]

39. Huang H, Liu YX, Zhan ZL, Liang H, Wang P, Ren XB. Different sites and prognoses of gastrointestinal stromal tumors of the stomach: report of 187 cases. World J Surg 2010;34:1523-33. [CrossRef]

40. Lasota J, Corless CL, Heinrich MC, Debiec-Rychter M, Sciot $\mathrm{R}$, Wardelmann E, et al. Clinicopathologic profile of gastrointestinal stromal tumors (GISTs) with primary KIT exon 13 or exon 17 mutations: a multicenter study on 54 cases. Mod Pathol 2008;21:476-84. [CrossRef]

41. Rubin BP. Gastrointestinal stromal tumours: an update [review]. Histopathology 2006;48:83-96. [CrossRef]

42. Ricci R, Dei Tos AP, Rindi G. GISTogram: a graphic presentation of the growing GIST complexity. Virchows Arch 2013;463:481-7. [CrossRef]

43. Peterson MR, Piao Z, Weidner N, Yi ES. Strong PDGFRA positivity is seen in GISTs but not in other intra-abdominal mesenchymal tumors: Immunohistochemical and mutational analyses. Appl Immunohistochem Mol Morphol 2006;14:390-6. [CrossRef]

44. Rossi G, Valli R, Bertolini F, Marchioni A, Cavazza A, Mucciarini C. PDGFR expression in differential diagnosis between KIT-negative gastrointestinal stromal tumours and other primary soft-tissue tumours of the gastrointestinal tract. Histopathology 2005;46:522-31. [CrossRef] 